\title{
COVID-19-related acute necrotizing encephalopathy with brain stem involvement in a patient with aplastic anemia
}

Luke Dixon, FRCR, James Varley, PhD, Anastassia Gontsarova, FRCR, Dermot Mallon, PhD, Francesca Tona, MD, David Muir, MRCPath, Asad Luqmani, FRCPath, leuan Harri Jenkins, MD, Richard Nicholas, PhD, Brynmor Jones, FRCR, and Alex Everitt, PhD

Neurol Neuroimmunol Neuroinflamm 2020;7:e789. doi:10.1212/NXI.0000000000000789

\section{Abstract}

\section{Objective}

To describe a novel case of coronavirus disease 2019 (COVID-19)-associated acute necrotizing encephalopathy (ANE) in a patient with aplastic anemia where there was early brain stempredominant involvement.

\section{Methods}

Evaluation of cause, clinical symptoms, and treatment response.

\section{Results}

A 59-year-old woman with a background of transfusion-dependent aplastic anemia presented with seizures and reduced level of consciousness 10 days after the onset of subjective fever, cough, and headache. Nasopharyngeal swab testing for severe acute respiratory syndrome coronavirus (SARS-CoV-2) was positive, and CT during admission demonstrated diffuse swelling of the brain stem. She required intubation and mechanical ventilation for airway protection, given her reduced level of consciousness. The patient's condition deteriorated, and MRI on day 6 demonstrated worsening brain stem swelling with symmetrical hemorrhagic lesions in the brain stem, amygdalae, putamina, and thalamic nuclei. Appearances were consistent with hemorrhagic ANE with early brain stem involvement. The patient showed no response to steroid therapy and died on the eighth day of admission.

\section{Conclusions}

COVID-19 may be associated with an acute severe encephalopathy and, in this case, was considered most likely to represent an immune-mediated phenomenon. As the pandemic continues, we anticipate that the spectrum of neurologic presentation will broaden. It will be important to delineate the full clinical range of emergent COVID-19-related neurologic disease.

\author{
Correspondence \\ Dr. Dixon \\ Luke.dixon1@nhs.net
}

\section{MORE ONLINE}

COVID-19 Resources

For the latest articles, invited commentaries, and blogs from physicians around the world NPub.org/COVID19 


\section{Glossary}

ANE = acute necrotizing encephalopathy; COVID-19 = coronavirus disease 2019; GCS = Glasgow Coma Score; GTCS = generalized tonic-clonic seizure; SARS-CoV-2 = severe acute respiratory syndrome coronavirus 2 .

Coronavirus disease 2019 (COVID-19) is caused by severe acute respiratory syndrome coronavirus 2 (SARS-CoV-2) and, was first detected in the human population in late December 2019. As of April 30, 2020, over 3 million cases have been reported worldwide and over 230,000 people have died from the infection. The typical presentation of SARS-CoV-2 with fever and respiratory symptoms is well recognized, although there is comparatively little reported on the neurologic sequelae. Despite the paucity of reported cases, there is increasing evidence that patients with severe COVID-19 often develop neurologic manifestations such as impaired consciousness. ${ }^{1}$ There have been reported cases of COVID19-associated encephalopathy and a single case of presumptive COVID-19-related acute necrotizing hemorrhagic encephalopathy associated with symmetrical hemorrhagic, necrotic lesions in both the thalamic nuclei and amygdalae. ${ }^{2}$ Here, we report a further case of possible COVID-19-related necrotizing hemorrhagic encephalopathy associated with early brain stem involvement.

\section{Case report}

A 59-year-old woman presented to the emergency department with recurrent fleeting episodes of vacant staring and speech arrest associated with flexion of both shoulders and a brief witnessed generalized tonic-clonic seizure (GTCS), followed by postictal reduced consciousness. Shortly after arrival in the emergency department, the patient vomited and had a further GTCS. She had a history of aplastic anemia treated with intermittent red blood cell and platelet transfusions. The patient had no significant paroxysmal nocturnal hemoglobinuria clone. She had received immunosuppressive therapy in the past, but not recently. She had returned from a trip to Afghanistan 3 weeks before presentation and developed transient abdominal pain and diarrhea. Ten days before her neurologic presentation, she developed a persistent cough, sore throat, shivering, and headache, with subsequent shortness of breath and myalgia. Three days before presentation, she had a routine telephone hematology clinic consultation and the following day underwent a blood test (table, day-2) which showed a stable platelet count $(33 \times$ $10^{9} / \mathrm{L}$ ), anemia (hemoglobin $103 \mathrm{~g} / \mathrm{L}$ ), and leukopenia (total white cell count $3.8 \times 10^{9} / \mathrm{L}$, lymphocyte count $1.4 \times$ $10^{9} / \mathrm{L}$, neutrophil count $\left.1.8 \times 10^{9} / \mathrm{L}\right)$.

Physical examination revealed reduced consciousness with a Glasgow Coma Score (GCS) of 11 of 15, body temperature of $36.9^{\circ} \mathrm{C}$, blood pressure of $130 / 63 \mathrm{~mm} \mathrm{Hg}$, pulse of 82 beats per minute, respiratory rate of 22 breaths per minute, and oxygen saturation of $97 \%$ on ambient air. Neurologic assessment found no focal deficits. Chest radiography showed right basal consolidation, and a CT scan of the head showed early swelling of the brain stem (figure 1). On admission, her blood cell count showed unchanged anemia and thrombocytopenia (platelet count $29 \times 10^{9} / \mathrm{L}$ ) which was consistent with the patient's history of aplastic anemia (table). Unlike previous blood counts, there was new lymphopenia (lymphocytes 0.3 from 1.42 days earlier). Nasopharyngeal swab RT-PCR testing for SARS-CoV-2 returned positive, thus confirming a diagnosis of COVID-19. The patient was started on levetiracetam and IV ceftriaxone, aciclovir, amoxicillin, and clarithromycin. In light of the severe thrombocytopenia and risk of hemorrhage, human leukocyte antigen-matched platelets (because of known platelet HLA antibodies) were transfused intermittently to maintain the platelet count $>50 \times 10^{9} / \mathrm{L}$.

Twelve hours after admission, the patient's GCS fell to 5 (E1, V1, and M3), with associated development of an extensor left plantar response and an unreactive left pupil. Although the patient's respiratory symptoms remained relatively mild, she underwent endotracheal intubation for airway protection and was transferred to the intensive care unit for mechanical ventilation. Repeat head CT showed increased hypodensity and swelling of the brain stem, and a new area of cortical and subcortical hypodensity in the left occipital lobe initially suggested an acute posterior circulation infarct. A subsequent computed tomography angiogram excluded an acute vascular occlusion but showed worsening brain stem swelling with subtle intrinsic pontine hemorrhage and new symmetrical hypodensities in the deep gray matter and amygdalae (figure 1). Appearances were suggestive of a rapidly evolving encephalopathy with severe involvement of the brain stem. On the fifth day of admission, lumbar puncture was performed immediately after platelet transfusion. CSF opening pressure was $28 \mathrm{~cm}$ water, and CSF analysis showed increased protein concentration $(2.3 \mathrm{~g} / \mathrm{L})$ and a normal white cell count of $4 / \mathrm{mm}^{3}$. Subsequent standard CSF virology PCR (herpes simplex virus 1 and 2, varicella zoster virus, adenovirus, cytomegalovirus, Epstein-Barr virus, enterovirus, parechovrius, and human herpesvirus 6), CSF PCR for SARS-CoV-2, and CSF culture were negative.

On the sixth day of admission, an MRI of the head demonstrated extensive, relatively symmetrical changes throughout the supratentorial and infratentorial compartments. There was diffuse swelling and hemorrhage in the brain stem and both amygdalae. Extensive abnormal signal and microhemorrhage were found in a symmetrical distribution within the dorsolateral putamina, ventrolateral thalamic nuclei, subinsular regions, splenium of the corpus callosum, cingulate gyri, and subcortical 
Table Clinical laboratory results

\begin{tabular}{|c|c|c|c|c|c|c|}
\hline Day of COVID-19 symptoms & 7 & 10 & 11 & 12 & 14 & 16 \\
\hline Day of admission & -2 & 0 & 1 & 3 & 5 & 7 \\
\hline Hemoglobin (g/L, 114-150) & 103 & 105 & 98 & 79 & 71 & 62 \\
\hline WBC $\left(10^{9} / \mathrm{L}, 4.2-11.2\right)$ & 3.8 & 3.2 & 5.1 & 2.9 & 2.4 & 3.3 \\
\hline Neutrophils $\left(10^{9} / \mathrm{L}, 2.0-7.1\right)$ & 1.8 & 2.7 & 4.3 & 2.5 & 1.6 & 2.5 \\
\hline Lymphocytes $\left(10^{9} / \mathrm{L}, 1.1-3.6\right)$ & 1.4 & 0.3 & 0.5 & 0.3 & 0.6 & 0.6 \\
\hline Monocytes $\left(10^{9} / L, 0.3-0.9\right)$ & 0.6 & 0.2 & 0.3 & 0.1 & 0.2 & 0.2 \\
\hline Platelets $\left(10^{9} / \mathrm{L}, 135-400\right)$ & 33 & 29 & 66 (post platelets) & 51 & 47 & 65 \\
\hline Sodium (mmol/L, 133-146) & 139 & 135 & 140 & 150 & 149 & 144 \\
\hline Potassium (mmol/L, 3.5-5.3) & 3.6 & 3.9 & 3.2 & 3.8 & 3.2 & 3.6 \\
\hline Blood urea nitrogen (mmol/L, 2.5-7.8) & 2.5 & 4.3 & 4.9 & 8.5 & 7.1 & 6.6 \\
\hline Creatinine (umol/L, 55-110) & 104 & 101 & 105 & 116 & 116 & 113 \\
\hline Corrected calcium (mmol/L, 2.2-2.6) & & 2.16 & 2.07 & 2.17 & 1.98 & 2.1 \\
\hline ALT (unit/L, 0-34) & 11 & 17 & 13 & 11 & 9 & 13 \\
\hline Total bilirubin (umol/L, 0-21) & 8 & 8 & 12 & 9 & 6 & 5 \\
\hline CRP (mg/L, 0.0-5.0) & 6.8 & 8.1 & 8.0 & 105.8 & 91.8 & 144.9 \\
\hline Ferritin (ug/L, 20-300) & & & 98 & 253 & 314 & 544 \\
\hline D-dimer (ng/mL <500) & & & 2033 & 1,203 & 1997 & 2044 \\
\hline Creatine kinase (unit/L) & & & & & 54 & 55 \\
\hline Troponin (ng/L) & & & 19 & 24 & & \\
\hline
\end{tabular}

Abbreviations: ALT = alanine transaminase; COVID-19 = Coronavirus disease 2019; CRP = C-reactive protein; WBC = white blood cell count.

perirolandic regions (figure 2). These regions demonstrated severe swelling and restricted diffusion with peripheral enhancement (figure 3). There was partial effacement of the ventricles, temporal uncal herniation, effacement of the basal cisterns, and moderate cerebellar tonsillar herniation secondary to the severe cerebral and pontine swelling. Overall imaging features supported a diffuse hemorrhagic acute necrotizing encephalopathy (ANE) with involvement of the brain stem. Neurologic examination after withdrawal of sedation revealed intact corneal reflexes and normal pupillary

Figure $1 \mathrm{CT}$ of the head findings over time

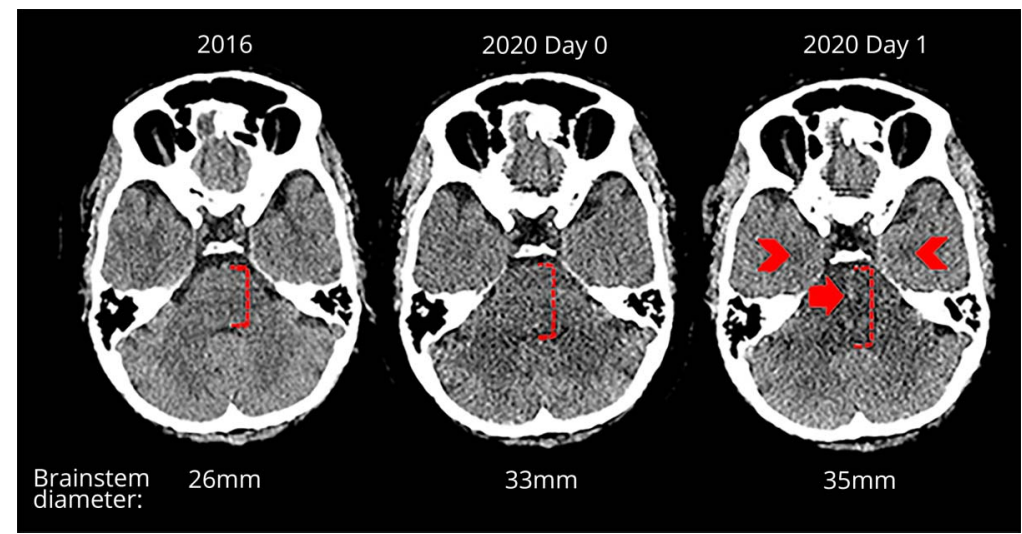

Axial CT head images on different dates. From left to right, premorbid previous CT performed in 2016, 2020 day 0 admission CT, and day 1 follow-up CT. Early admission CT demonstrates subtle new swelling of the brain stem, and the follow-up CT 1 day later shows progression of the swelling with new central hemorrhagic foci (closed arrow) and symmetrical hypodensities in both amygdalae (chevrons). On day 1 of the follow-up $C T$, there was also hypodensity in both thalami and dorsolateral putamina (not shown). 


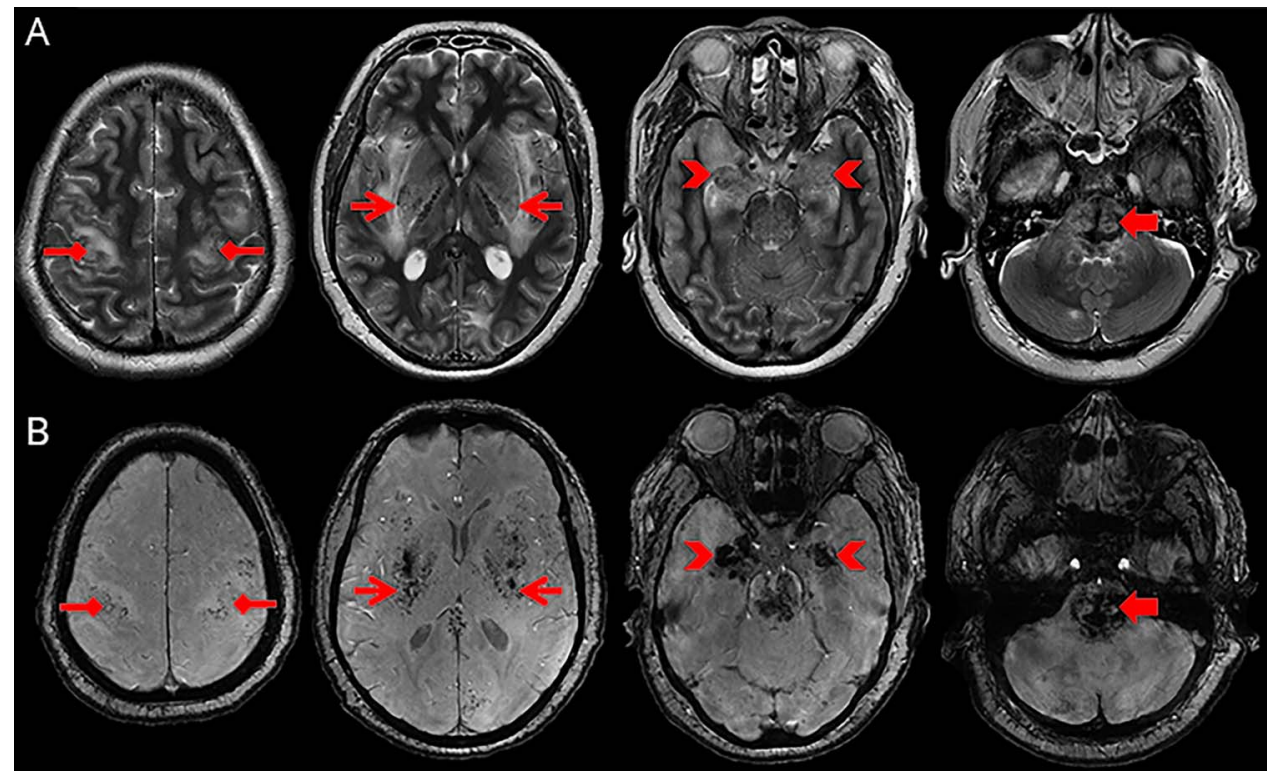

Serial T2-weighted (A) and susceptibility-weighted (B) axial MRI images of the brain demonstrating abnormal swelling and T2-weighted signal (A) with intrinsic hemorrhage (B) in the subcortical perirolandic regions ( $\mathrm{di}$ amond arrow heads), dorsolateral putamina, ventrolateral thalamic nuclei and subinsular regions (open arrow heads), amygdalae (chevrons) and, pons (closed arrow heads). Abnormal signal is also shown in the splenium of the corpus callosum and cingulate gyri (not labeled).

responses to light. Doll's eye response was reduced. She coughed on suction and initiated breathing but required pressure support mechanical ventilation. She displayed no response to verbal command or painful stimuli. However, based on the severity of the MRI findings, the patient was deemed to have a very poor neurologic prognosis. She showed no sign of neurologic improvement after high dose dexamethasone and on the 10th day of admission died after the withdrawal of ventilatory support. Her family declined a postmortem study.

\section{Discussion}

To our knowledge, we report the second case of presumptive COVID-19-related hemorrhagic ANE. Similar to the previously reported case, our patient had relatively symmetrical hemorrhagic lesions in the amygdalae and thalamic nuclei although, by contrast, there was also extensive involvement of the pons and medulla and, to a lesser extent, the striatum and subcortical perirolandic regions. ${ }^{2}$ In our case, the patient's aplastic anemia

Figure 3 Diffusion weighted and contrast-enhanced T1-weighted MRI head at day 6

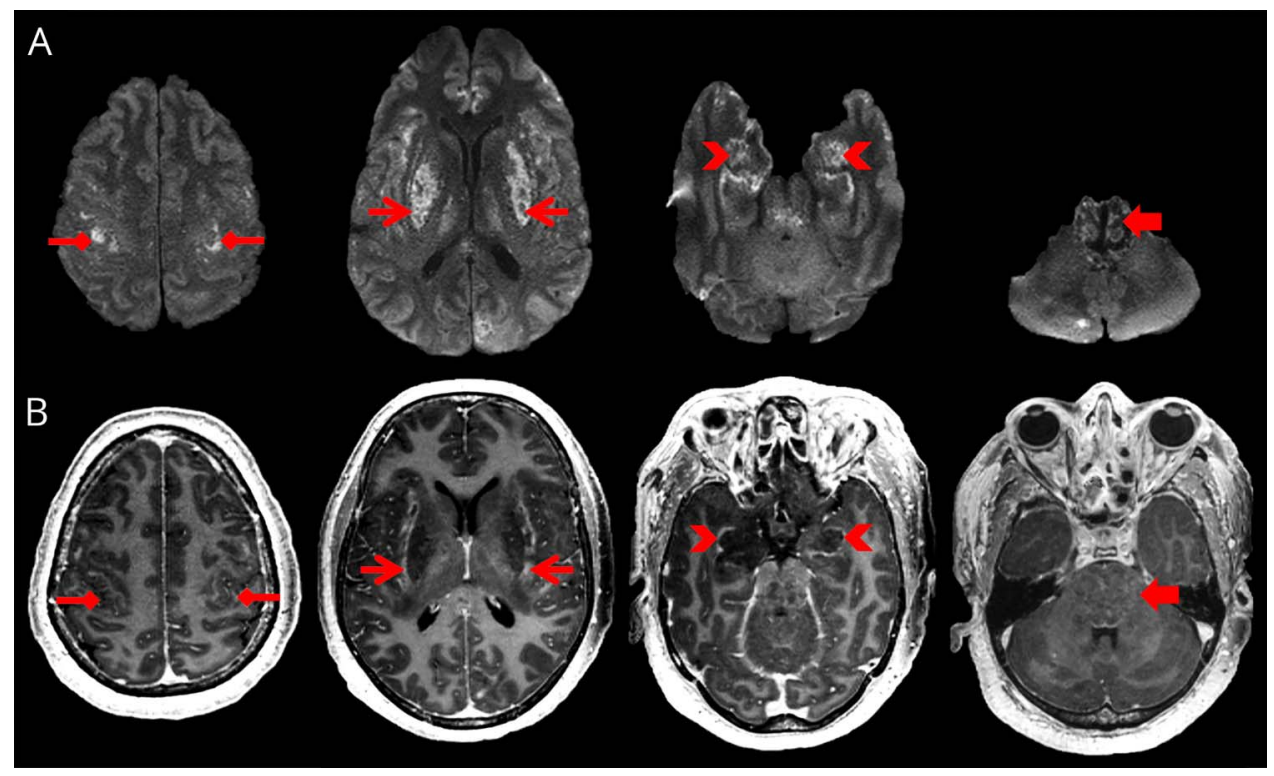

Serial diffusion-weighted imaging (A) and contrast-enhanced T1-weighted (B) axial MRI images of the brain demonstrating abnormal restricted diffusion (A) and peripheral enhancement (B) in the same areas as the abnormal T2-weighted signal. Namely, the subcortical perirolandic regions (diamond arrow heads), dorsolatera putamina, ventrolateral thalamic nuclei and subinsular regions (open arrow heads), amygdalae (chevrons), and pons (closed arrow heads). Restricted diffusion is also shown in the splenium of the corpus callosum and cingulate gyri (not labeled). 
with severe thrombocytopenia likely contributed to the hemorrhagic component of the encephalopathy. However, outside of bone marrow transplantation and active immunosuppressant therapy, there is no reported predisposition to encephalopathy in patients with aplastic anemia. ${ }^{3,4}$ Our patient was not lymphopenic before COVID-19, and therefore, it is unlikely that the aplastic anemia caused an impaired immune response.

ANE is a rare encephalopathy most frequently encountered in children and characterized by multiple, symmetrical lesions in the thalami, striatum, cerebral white matter, and brain stem. ${ }^{5,6}$ ANE has previously been linked to several infective agents including influenza-A, herpes simplex virus, influenza-B, mycoplasma, and human herpes virus- $6 .{ }^{6,7}$ As in this case, ANE is often rapidly progressive with seizures, reduced consciousness, and vomiting, usually occurring 12-72 hours after symptom onset of the viral infection. ${ }^{5,7}$ As in our case, CSF analysis frequently shows an elevated protein concentration but a normal white blood cell count. ${ }^{5,7}$ The precise etiology and pathophysiology of ANE remains unclear. In reported cases, the suspected causative pathogen is rarely detected in the CSF by PCR assay. ${ }^{5,7}$ In an autopsy of a patient with ANE secondary to H1N1 influenza, a notable absence of perivascular or meningeal inflammation was found. ${ }^{6}$ Therefore, ANE is not believed to be a product of direct infection but the result of an immune-mediated process involving proinflammatory cytokines. ${ }^{8,9}$ A possible hyperinflammatory response in COVID-19 is supported by the recent observation that COVID-19-related acute respiratory distress syndrome may be driven by a macrophage activation syndrome or cytokine storm. ${ }^{10}$ Unfortunately, in our case, testing for interleukins in the serum or CSF was not possible. Despite this, an immunemediated phenomenon, as opposed to a neurotropic effect, is suggested because CSF RT-PCR testing for SARS-CoV-2 was negative and no other potential causative agent was identified.

Further exploration of potential COVID-19-related CNS pathology is needed and requires national and international collaboration to collect large, organized data sets. The possibility of an immune-mediated process and its therapeutic implications also warrants greater study.

\section{Study funding}

No targeted funding reported.

\section{Disclosure}

L. Dixon, J. Varley, A. Gontsarova, D. Mallon, F Tona, D. Muir, A. Luqmani, I. Jenkins, R. Nicholas, B. Jones, and A. Everitt reports no disclosures. Go to Neurology.org/NN for full disclosures.

\section{Publication history}

Received by Neurology: Neuroimmunology \& Neuroinflammation April 14, 2020. Accepted in final form May 5, 2020.

\section{Appendix Authors}

\begin{tabular}{lll}
\hline Name & Location & Contributions \\
\hline Luke Dixon & $\begin{array}{l}\text { Department } \\
\text { of Imaging, Imperial } \\
\text { College Healthcare } \\
\text { NHS Trust, London, }\end{array}$ & $\begin{array}{l}\text { Data acquisition, } \\
\text { drafting/revising } \\
\text { the manuscript, } \\
\text { UK. }\end{array}$ \\
& $\begin{array}{l}\text { analysis or } \\
\text { interpretation of } \\
\text { the data, and } \\
\text { study concept or } \\
\text { design }\end{array}$ \\
& \\
\end{tabular}

\begin{tabular}{lll}
\hline James Varley & $\begin{array}{l}\text { Department of } \\
\text { Neurosciences, } \\
\text { Imperial College } \\
\text { Healthcare NHS } \\
\text { Trust, London, UK. }\end{array}$ & $\begin{array}{l}\text { Data acquisition, } \\
\text { drafting/revising } \\
\text { the manuscript, } \\
\text { and analysis or } \\
\text { interpretation of } \\
\text { the data }\end{array}$ \\
\hline Anastassia Gontsarova & $\begin{array}{l}\text { Department of } \\
\text { Imaging, Imperial } \\
\text { College Healthcare } \\
\text { NHS Trust, London, } \\
\text { UK. }\end{array}$ & $\begin{array}{l}\text { Data acquisition } \\
\text { and analysis or } \\
\text { interpretation of } \\
\text { the data }\end{array}$ \\
\hline Dermot Mallon & $\begin{array}{l}\text { Department of } \\
\text { Imaging, Imperial } \\
\text { College Healthcare } \\
\text { NHS Trust, London, } \\
\text { UK. }\end{array}$ & $\begin{array}{l}\text { Drafting/revising } \\
\text { the manuscript }\end{array}$ \\
\hline
\end{tabular}

\begin{tabular}{lll}
\hline Francesca Tona & Department of & $\begin{array}{l}\text { Drafting/revising } \\
\text { Imaging, Imperial }\end{array}$ \\
& College Healthcare & \\
& NHS Trust, London, & \\
& UK.
\end{tabular}

\begin{tabular}{lll}
\hline David Muir & $\begin{array}{l}\text { Northwest London } \\
\text { Pathology, UK }\end{array}$ & $\begin{array}{l}\text { Drafting/revising } \\
\text { the manuscript }\end{array}$ \\
\hline Asad Luqmani & $\begin{array}{l}\text { Department of } \\
\text { Hematology, } \\
\text { Imperial College } \\
\text { Healthcare NHS } \\
\text { Trust, London, UK. }\end{array}$ & $\begin{array}{l}\text { Data acquisition } \\
\text { and analysis or } \\
\text { interpretation of } \\
\text { the data }\end{array}$ \\
\hline leuan Harri Jenkins & $\begin{array}{ll}\text { Department of } \\
\text { Neurosciences, } \\
\text { Imperial College } \\
\text { Healthcare NHS } \\
\text { Trust, London, UK. }\end{array}$ & $\begin{array}{l}\text { Data acquisition, } \\
\text { drafting/revising } \\
\text { the manuscript, } \\
\text { and analysis or } \\
\text { interpretation of } \\
\text { the data }\end{array}$ \\
\hline & & Data acquition
\end{tabular}

Richard Nicholas Centre for Data acquisition
Neuroinflammation and analysis or and interpretation of Neurodegeneration, the data Faculty of Medicine, Imperial College London, London, UK. \& Department of Visual Neuroscience, UCL Institute of Ophthalmology, London, UK.

\begin{tabular}{lll}
\hline Brynmor Jones & $\begin{array}{l}\text { Department of } \\
\text { Imaging, Imperial } \\
\text { College Healthcare }\end{array}$ & $\begin{array}{l}\text { Data acquisition, } \\
\text { drafting/revising } \\
\text { NHS Trust, London, }\end{array}$ \\
the manuscript, & $\begin{array}{l}\text { analysis or } \\
\text { interpretation of } \\
\text { UK. }\end{array}$ \\
& $\begin{array}{l}\text { the data, and } \\
\text { study concept or } \\
\text { design }\end{array}$ \\
\end{tabular}

Continued 
Appendix (continued)

\begin{tabular}{|c|c|c|}
\hline Name & Location & Contributions \\
\hline Alex Daniel Everitt & $\begin{array}{l}\text { Department of } \\
\text { Neurosciences, } \\
\text { Imperial College } \\
\text { Healthcare NHS } \\
\text { Trust, London, UK. }\end{array}$ & $\begin{array}{l}\text { Data acquisition, } \\
\text { drafting/revising } \\
\text { the manuscript, } \\
\text { analysis or } \\
\text { interpretation of } \\
\text { the data, study } \\
\text { concept or } \\
\text { design, and Study } \\
\text { Supervision }\end{array}$ \\
\hline
\end{tabular}

\section{References}

1. Mao L, Jin H, Wang M, et al. Neurologic manifestations of hospitalized patients with coronavirus disease 2019 in Wuhan, China. JAMA Neurol Epub 2020 April 10. doi: 10.1001/ jamaneurol.2020.1127.

2. Poyiadji N, Shahin G, Noujaim D, Stone M, Patel S, Griffith B. COVID-19-associated acute hemorrhagic necrotizing encephalopathy: CT and MRI features. Radiology Epub 2020 Mar 31. doi: 10.1148/radiol.2020201187.
3. Mashima K, Yano S, Yokoyama H, et al. Epstein-barr virus-associated lymphoproliferative disorder with encephalitis following anti-thymocyte globulin for aplastic anemia resolved with rituximab therapy: a case report and literature review. Intern Med 2017;56:701-706.

4. Tam DYS, Cheng FWT, Chan PKS, et al. Intact survival of refractory CMV limbic encephalitis in a patient with severe aplastic anemia after unrelated bone marrow transplantation. J Pediatr Hematol Oncol 2012;34:472-474.

5. Wong AM, Simon EM, Zimmerman RA, Wang HS, Toh CH, Ng SH. Acute necrotizing encephalopathy of childhood: correlation of MR findings and clinical outcome. Am J Neuroradiol 2006;27:1919-1923.

6. Offiah C, Hall E. Acute necrotizing encephalopathy associated with novel influenza H1N1 (pdm09) infection: MRI and correlation with brain necropsy. J Pediatr Neuroradiol 2013;2:319-324

7. Mizuguchi M. Acute necrotizing encephalopathy of childhood: a novel form of acute encephalopathy prevalent in Japan and Taiwan. Brain Dev 1997;19:81-92.

8. Sugaya N. Influenza-associated encephalopathy in Japan: pathogenesis and treatment. Pediatr Int 2000;42:215-218.

9. Ito $\mathrm{Y}$, Ichiyama $\mathrm{T}$, Kimura $\mathrm{H}$, et al. Detection of influenza virus RNA by reverse transcription-PCR and proinflammatory cytokines in influenza-virus-associated encephalopathy. J Med Virol 1999;58:420-425.

10. McGonagle D, Sharif K, O'Regan A, Bridgewood C. The role of cytokines including interleukin-6 in COVID-19 induced pneumonia and macrophage activation syndrome-like disease. Autoimmun Rev 2020:102537. 


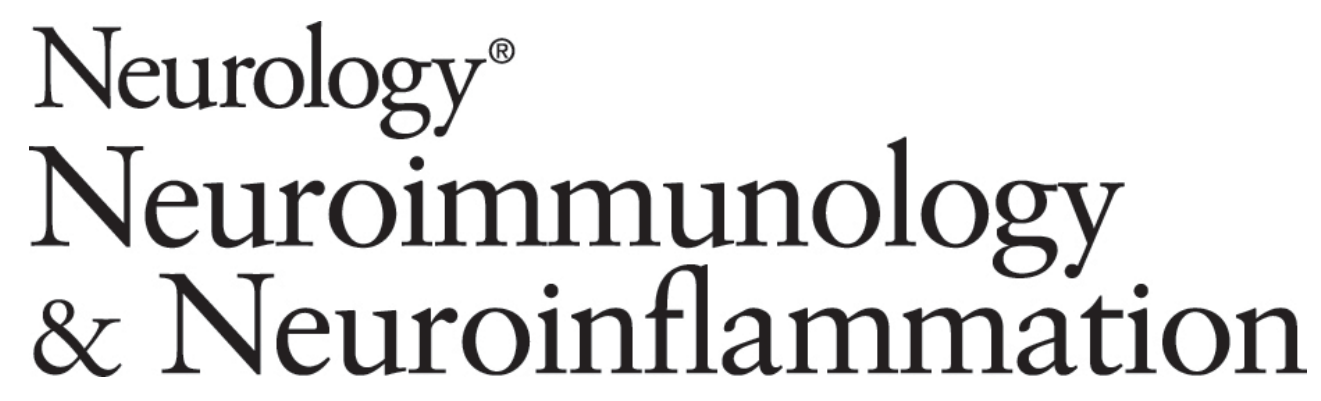

COVID-19-related acute necrotizing encephalopathy with brain stem involvement in a patient with aplastic anemia

Luke Dixon, James Varley, Anastassia Gontsarova, et al.

Neurol Neuroimmunol Neuroinflamm 2020;7;

DOI 10.1212/NXI.0000000000000789

This information is current as of May 26, 2020

Neurol Neuroimmunol Neuroinflamm is an official journal of the American Academy of Neurology.

Published since April 2014, it is an open-access, online-only, continuous publication journal. Copyright

Copyright $\odot 2020$ The Author(s). Published by Wolters Kluwer Health, Inc. on behalf of the American

Academy of Neurology.. All rights reserved. Online ISSN: 2332-7812.

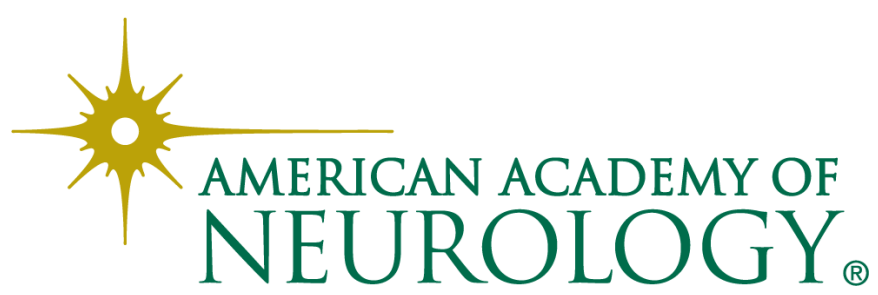




\section{Updated Information \& Services}

References

Citations

Subspecialty Collections

Permissions \& Licensing

Reprints including high resolution figures, can be found at: http://nn.neurology.org/content/7/5/e789.full.html

This article cites 9 articles, 0 of which you can access for free at: http://nn.neurology.org/content/7/5/e789.full.html\#\#ref-list-1

This article has been cited by 10 HighWire-hosted articles: http://nn.neurology.org/content/7/5/e789.full.html\#\#otherarticles

This article, along with others on similar topics, appears in the following collection(s):

\section{COVID-19}

http://nn.neurology.org//cgi/collection/covid_19

Encephalitis

http://nn.neurology.org//cgi/collection/encephalitis

MRI

http://nn.neurology.org//cgi/collection/mri

Viral infections

http://nn.neurology.org//cgi/collection/viral_infections

Information about reproducing this article in parts (figures,tables) or in its entirety can be found online at:

http://nn.neurology.org/misc/about.xhtml\#permissions

Information about ordering reprints can be found online:

http://nn.neurology.org/misc/addir.xhtml\#reprintsus

Neurol Neuroimmunol Neuroinflamm is an official journal of the American Academy of Neurology.

Published since April 2014, it is an open-access, online-only, continuous publication journal. Copyright

Copyright $\odot 2020$ The Author(s). Published by Wolters Kluwer Health, Inc. on behalf of the American

Academy of Neurology.. All rights reserved. Online ISSN: 2332-7812.

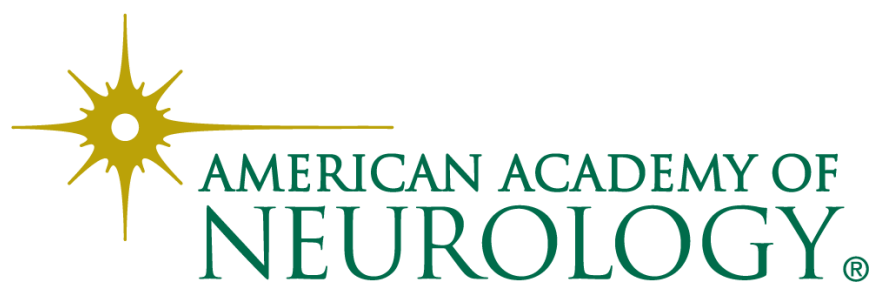

